\title{
DUAL NATURE OF INDUSTRIAL ENTERPRISE COST MANAGEMENT SYSTEM
}

\author{
Natalia Radionova ${ }^{1}$, Margaryta Skrypnyk ${ }^{2}$, Tayisiya Voronkova ${ }^{3}$
}

\begin{abstract}
The research subject is the cost management system of an industrial enterprise. The purpose of the article is the theoretical substantiation of the methodical aspects of the cost management system as a part of the industrial enterprise management system. Each company pays attention to the formation of costs because they affect the financial results. The improvement of the enterprise management system in modern economic conditions will not be effective without the establishment of a functional efficient cost management system, the formation of which is advisable to implement using both domestic and international practices. However, not every Ukrainian industrial enterprise has an efficient cost management system that optimizes the level of costs. Methodology. The empirical and theoretical methods such as analysis and synthesis, logical approach, interpretation, modelling, and visual systematization using the graphical method have been used in the work. The article considers the place of the cost management system in the management system of an industrial enterprise. There has been shown the influence of the cost management system on the strategic and tactical purpose of the enterprise. Subsystems of the cost management system have been considered and their components have been disclosed. Functions of the cost management system have been presented and the value of each subsystem element has been considered. The structure of the cost management system in the enterprise management system is clearly represented. Practical implications. An efficiently operating cost management system cannot only be aimed at an enterprise's surviving in today's market conditions. It should facilitate the implementation of tactical and strategic enterprise goals. As tactical goals, we can note the growth of enterprise profitability. The enterprise strategic goal in a market environment is to increase its value. However, the efficient cost management is a rather complicated process, because costs are variable and consist of numerous elements of different content and origin depending on various factors that are sensitive to the external environment, often have a controversial composition and are hardly subjected to the desired regulation. Value/originality. The system approach has revealed the dual nature of the company's cost management system. On the one hand, the enterprise cost management system is a subsystem of the enterprise management system. On the other hand, the cost management system can be considered as an independent system, which includes subsystems and a set of interconnected elements that interact with each other to achieve a high economic performance of the enterprise. Among the subsystems, there have been distinguished economic and functional, organizational and managerial. For the formation of the economic and functional subsystem, M. Porter's approach to the creation of the value chain of production was used. Moreover, the value chain for an industrial enterprise should start not from the material and technical supply, as M. Porter proposed, but from the study of market demand for products.
\end{abstract}

Key words: enterprise management system, cost management system, cost optimization, industrial enterprise, value chain.

JEL Classification: D24, L11, M11, M31

\footnotetext{
Corresponding author:

${ }^{1}$ Kyiv National University of Technologies and Design, Ukraine.

E-mail: radionova_n@ukr.net

ORCID: https://orcid.org/0000-0002-8855-2963

${ }^{2}$ Kyiv National University of Technologies and Design, Ukraine.

E-mail: margarita1111@ukr.net

ORCID: https://orcid.org/0000-0002-6205-0754

${ }^{3}$ Kyiv National University of Technologies and Design, Ukraine.

E-mail: taya48@i.ua

ORCID: https://orcid.org/0000-0002-8648-117X
} 


\section{Introduction}

The current level of the economic condition of industrial enterprises necessitates not only cost management but also the development of a cost management system that would ensure that the company achieves its tactical and strategic goals. The study of the research subject on cost management has led to the conclusion that, in general, as a system, it is not presented in the economic literature. Only separate elements of the cost management system, each of which achieves a certain set of goals and is practically not related to others, are elaborated in detail. Therefore, based on the existing theories, we give our vision of the essence of the enterprise cost management system. The purpose of the article is the theoretical substantiation of the methodical aspects of the cost management system as a part of the industrial enterprise management system.

Scientific works investigation allows distinguishing the basic approaches to the costs' interpretation as a category. For example, M. G. Chumachenko and I. P. Bilousova interpret costs from the point of view of the resources use for the enterprise's work (Chumachenko, Bilousova, 2008). Within the economic approach, costs are interpreted from the position of cost factors, to achieve the financial result (Skrypnyk, 2011). The accounting approach proposes linking costs with the enterprise's assets and liabilities (Deriy, 2015). V. Kozak asserts that costs directly influence management decisions (Kozak, 2019). The marketing approach considers costs as a factor affecting the products price (Harkavenko, 2007).

The issues concerning the enterprise cost management were highlighted in the works of Ukrainian and international scholars of economics, among them are A. A. Balan, V. A. Deriy, R. S. Kaplan, V. H. Kozak, G. V. Kozachenko, Yu. S. Pogorelov, G. A. Makukhin, M. Porter, M. I. Skrypnik, T. V. Taler, A. V. Cherep, M. G. Chumachenko, I. P. Bilousova, S. S. Harkavenko, M. I. Yudina. However, a wide range of theoretical, methodological, and applied issues related to the development of the cost management system at an industrial enterprise has not received a sufficiently complete and systemic solution in Ukrainian economy yet and needs further research.

\section{A comprehensive approach to cost management}

The analysis of scientificliterature shows that, according to most national and international economists, cost management is a process that represents a continuous, integrated impact of various factors on the costs of an enterprise in order to ensure their optimum level, structure, and dynamics. We believe that it is expedient to present the cost management process as a system since the cost management process should have an integrated approach, has to be related to all areas of the enterprise, and be sensitive to changes occurring in the external and internal environment (Figure 1).

Therefore, as we can see from Figure 1, the enterprise management is a holistic system that has its own subsystems (informational, technical and innovative, economic, production organization, and human resources management). Each subsystem performs its functions and has its own elements. Thus, the information subsystem reflects the aspects of regulatory, legislative, organizational, methodological, and analytical support of the enterprise management system. The technical and innovative subsystem includes technological and material support for the enterprise functioning and its development on an innovative basis.

The subsystem of the production organization is responsible for the development and coordination of production processes, the sequence of the enterprise technological operations. The subsystem of human resources management includes issues of the qualitative and quantitative composition of employees, their duties and relationships. The economic subsystem of the enterprise management system, controlling the use efficiency of production means and labour productivity, is responsible for not only optimizing the production volume and sales but also for achieving the tactical and strategic enterprise goals. The first goal includes economic viability, as a complex concept, since two indicators characterize the enterprise economic viability: profit and profitability.

It is possible to indicate an increase in the market value as a strategic goal of an enterprise in a market environment. Cost management is an element of the enterprise management system, which is interconnected with all its subsystems and has an impact on the tactical and strategic enterprise goal.

\section{Subsystems of the cost management system}

Consequently, cost management can be considered as a system having its own subsystems and elements.

The cost management system, like any other system, should consist of four main parts, from the morphological point of view. The first part is the object to which the action of this system is directed (in our case, it is the costs at different stages of the product life cycle). The second part is cost management functions (solutions development, implementation of solutions, control). The third part is a sequence of operations (algorithm, methodology, etc.). The fourth part includes the entities that perform all these operations, without which the system will not be able to function. These parts, together with the organizational structures that will ensure their functioning, constitute the organizational and managerial subsystem of the cost management system (Skrypnyk, 2011).

From our point of view, the cost management system has a dual nature, on the one hand, it is a subsystem of 


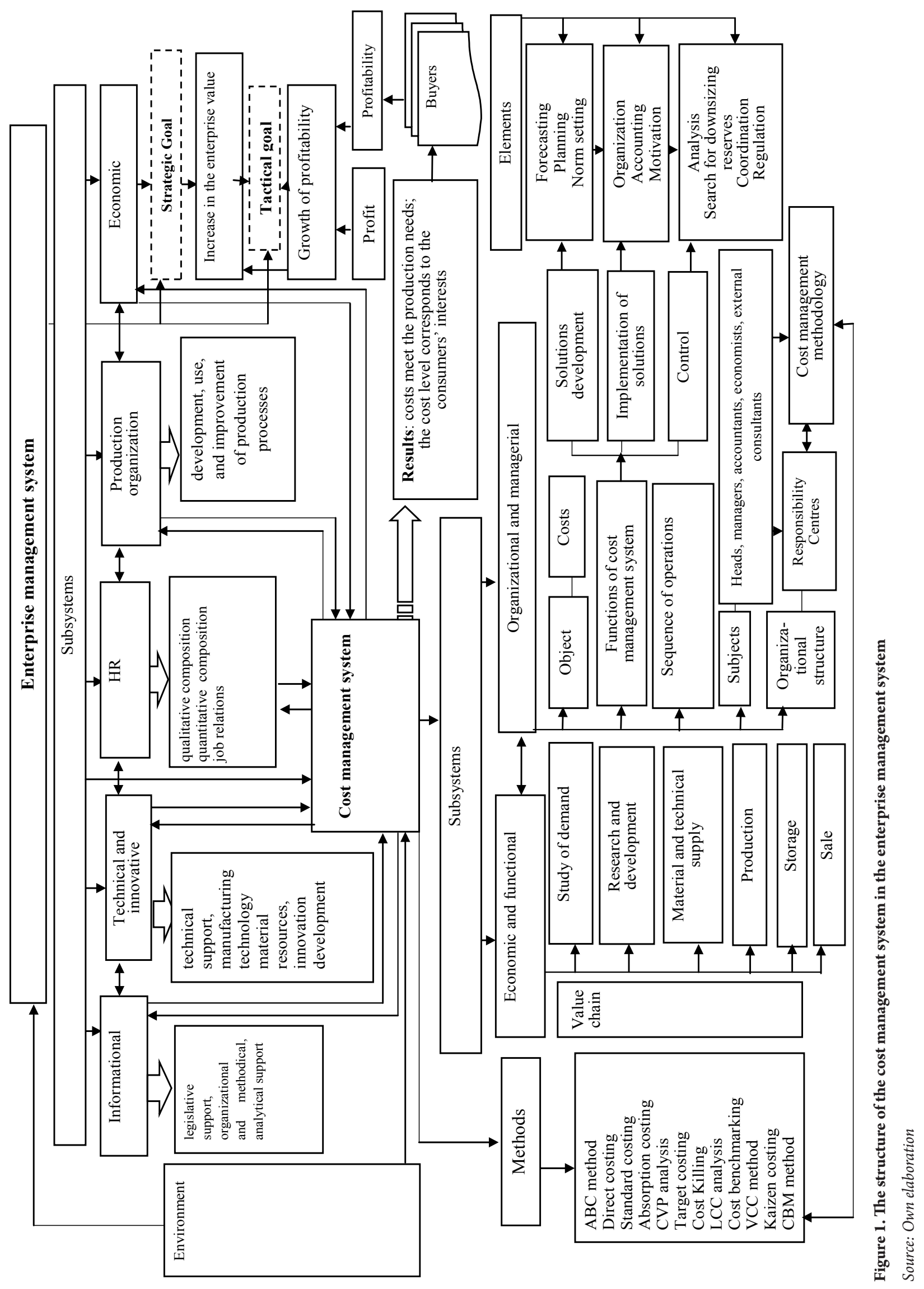


the enterprise management system (as an economic system of the higher level), which is under the influence of the enterprise management system. On the other hand, it acts as an independent hierarchical system (as an economic system of the lower level) that has its own subsystems, elements, functions, methods, that regulates the enterprise cost level, taking into account its strategic and tactical goals and technological and organizational peculiarities. In its turn, it affects the overall enterprise management system.

In addition to the organizational and management subsystem, we consider it expedient to distinguish an economic and functional subsystem in the cost management system. This subsystem will provide an effective value chain of production. Nowadays, special attention is paid to the formation of a value chain as a means of increasing the degree of consumers' satisfaction and more efficient cost management. Normally, a value chain is a set of activities that create value, ranging from input sources of raw materials (suppliers) to the manufacture of finished products delivered to the end user. We believe that the value chain of a garment business should be created not from suppliers of raw materials, as M. Porter predicted, but from market research on the demand study for finished products (Porter, 2005). Given that a modern industrial enterprise must implement innovative material and technical support, we propose to include the research and development costs into the value chain. Further, there are classical components - material and technical support, production, storage, realization.

The co-ordination of separate components of the value chain creates conditions for increasing the degree of consumer satisfaction with regard to price, quality and range and timely delivery of products. An enterprise that performs activities within the value chain works much more efficiently and at a lower cost than comparable manufacturers of competing products since all activities are not a set of independent components but constitute a system of interconnected steps when the results of one affect the costs of others.

\section{Methods of enterprise cost management}

To ensure the functioning of the cost management system, there are a large number of cost management methods ( $\mathrm{ABC}$ method, direct costing, standard costing, absorption costing, CVP analysis, target costing, cost killing, LCC analysis, cost benchmarking, VCC method, kaizen costing and others) (Kozachenko, 2007). It should be noted that each of the existing methods is not a universal tool for solving all enterprise problems; each method has its advantages and disadvantages. We believe that in order to obtain an efficient cost management system in modern conditions, it is necessary to apply an approach that will have the tools necessary for the enterprise to use different concepts, combining their individual elements into one method.

The existing methods of cost management research allowed to distinguish classical and modern approaches that take into account market factors (comparison with competitors, management of the target price, taking into account the life cycle of products, etc.), that is shown in Table 1.

To improve the enterprise cost management, we suggest applying a new methodological approach (CBM method). The CBM method has an integrated approach to solving problems of the industrial enterprise cost management because it takes into account technological and organizational factors of production and allows finding reserves of cost optimization at each technological stage.

Table 1

The general classification of cost management methods

\begin{tabular}{|l|l|l|}
\hline \multicolumn{2}{|c|}{ Traditional methods } & \multicolumn{1}{c|}{ Foreign practice } \\
\cline { 1 - 2 } $\begin{array}{l}\text { Normative - the method of costs by } \\
\text { norms and deviations }\end{array}$ & $\begin{array}{l}\text { Standard Costing System - cost method by } \\
\text { norms and deviations }\end{array}$ & Cost Volume Profit - distribution analysis \\
\hline $\begin{array}{l}\text { Procedure - accounting by the costs of } \\
\text { individual processes }\end{array}$ & $\begin{array}{l}\text { Direct Costing System - incomplete costs } \\
\text { method }\end{array}$ & $\begin{array}{l}\text { Target Costing - method of target price } \\
\text { management }\end{array}$ \\
\hline $\begin{array}{l}\text { Preliminary - allocation of costs for } \\
\text { redistribution of production }\end{array}$ & $\begin{array}{l}\text { Activity Based Costing - calculation by the } \\
\text { type of activity }\end{array}$ & $\begin{array}{l}\text { Life Cycle Costing - calculation of expenses } \\
\text { by the stages of the product life cycle }\end{array}$ \\
\hline $\begin{array}{l}\text { Ordered - cost accounting for individual } \\
\text { orders }\end{array}$ & $\begin{array}{l}\text { Absorption Costing - distribution of all costs } \\
\text { between sold products and product balances }\end{array}$ & $\begin{array}{l}\text { Benchmarking - comparison of costs with } \\
\text { leading enterprises }\end{array}$ \\
\cline { 2 - 3 } & $\begin{array}{l}\text { Killing Costing - maximum cost reduction } \\
\text { method }\end{array}$ & $\begin{array}{l}\text { Value Chain Costing - a method for managing } \\
\text { the value chain }\end{array}$ \\
\cline { 2 - 3 } & $\begin{array}{l}\text { Kaizen Costing - constant cost reduction } \\
\text { method }\end{array}$ & $\begin{array}{l}\text { Just-In-Time - the cost of the quantity of } \\
\text { products that is needed at the moment }\end{array}$ \\
& $\begin{array}{l}\text { Functional Cost Analysis - providing optimal } \\
\text { correlations between quality and cost }\end{array}$ \\
\cline { 3 - 4 } & $\begin{array}{l}\text { Strategic Cost Analysis - based on the sequence } \\
\text { of operations to create the value of the product }\end{array}$ \\
\hline
\end{tabular}

Source: compiled by the authors 


\section{Functions of the enterprise cost management system}

It should be noted that the enterprise cost management system provides fulfilling all functions and the availability of appropriate elements that are inherent in any object management (Balan, 2014).

The cost management starts with forecasting. Forecasting is a method that uses both experience and current assumptions about the future in order to determine it. If the forecasting is performed well, the result will be a picture of the future, which can be used as a basis for planning (Kaplan, 1998).

Forecasting is inextricably connected with planning. The next step is to develop a production plan since it will determine the level of planned and actual production costs in the future. The quality of this question solution depends on the extent to which the necessary conditions and limitations are fully taken into account. In our view, during planning, it is necessary to take into account the availability of available factors of production; the cost of material resources; price forecasts for manufactured products and possible scope of its realization. The task of planning a production program can be solved by means of known methods of linear programming, with special attention to the choice of the target function.

The cost planning is a system of technical and economic calculations, the purpose of which is to substantiate economically the current costs necessary for the production and marketing of enterprise industrial products in the planned period, which meets the requirements for the quality of these products in the conditions of market relations (Taler, 2006).

In particular, the planned cost calculations are used in profit planning, determining the economic efficiency of some organizational and technical measures and production in general, in the internal production planning, in establishing free (market) and government regulated wholesale prices for industrial products, as well as in determining the profitability level (Cherep, 2005).

The next step in the planning phase is defining the planned production costs for all types of resources used by the enterprise, based on cost centres. Then the planned value calculation of the production cost is performed and, in our opinion, this calculation should be done in two alternative options - full and subset. With elastic demand for manufactured products, this approach serves for pricing purposes.

There are different types of forecasting and cost planning used by enterprises. Therefore, at the stage of long-term planning, we resort to long-term planning, and at the stage of short-term planning - to the current one. Short-term plans are made for a month, a quarter, a year; long-term (perspective) plans determine the enterprise development for 3-5 years (for large enterprises - for a longer period).
The task of long-term planning is to choose an adequate variant of the enterprise activities based on the analysis of the chances and risks generated by the external, macroeconomic environment, strengths and weaknesses of the enterprise. It is necessary to forecast the expected conditions and changes in the external economic environment (to calculate the probability of recession, increased competition, higher inflation, etc.). In a market environment, every enterprise aspires for development: it is necessary to develop new products, to improve production, or to combine both of these directions. The development requires investment in new products development, the formation of sales markets, creation of technical and human resources, search for suppliers of material and technical resources.

Choosing a certain way of action, especially one that includes the involvement of resources in production for a long period, the enterprise management should have a clear idea of the amount of costs associated with the decision. Each considered scenario meets certain costs, which should be calculated at the long-term planning stage.

With regard to short-term planning, current plans specify the implementation of long-term goals of the enterprise.

Norm setting is a process of designing and approving norms and standards that set limits on the use of resources necessary to ensure the production process and sales of products (works, services). The purpose of cost regulation is to ensure the efficient use of resources through comprehensive efforts to reduce the total cost of production and sales of products. This can be achieved if in norm-setting the main attention will be paid to the possibilities of using modern high technologies and equipment and the appropriate production organization, labour, and management, which would reduce the cost of resources and timely reflect this decline in cost standards.

The organization is the most important element of effective cost management. At this stage, it is possible to establish how the enterprise manages costs, that is, who does it, in what period, what information and documentation are applied, what methods are used. Cost centres, cost places, and responsibility centres for compliance with cost guidelines are determined. A hierarchical system of linear and functional relationships between managers and specialists involved in cost management is developed. This system should be compatible with the organizational and production structure of the enterprise.

For the management process, it is difficult to overestimate the accounting value, which serves as a link between economic activity and enterprise management (Chumachenko, Bilousova, 2008). Accounting chronologically organizes and displays data on the enterprise economic activity through their registration for further use. In accounting procedures, 
cost data are processed, stored up to the right moment, and then presented in such a way that they become useful information. Information in the form of reports is transmitted to the company's management for making the best decisions.

Motivation is intended to intensify and stimulate research into such ways of influencing the production participants, which would encourage compliance with the established cost plan and find ways to reduce them. For this purpose, both material and moral factors of encouragement are applied.

The cost analysis is a process of reflecting the use of costs and results of past, present, and future production activities of a relevant management model oriented towards the main goal of the enterprise (Yudina, 2013). Such an analysis as an element of cost management is necessary for information preparation in order to make effective business decisions. For example, in assessing the required amount of material inventories, future costs are determined by forecasting based on the analysis and the information on actual costs is provided by accounting.

The cost analysis, which forms an element of the control function, helps to assess the efficiency of utilizing all enterprise resources, to identify reserves for reducing production costs, to gather information for preparing plans and making sound management decisions regarding costs.

The search for cost optimization is aimed at its rational reduction in achieving the optimal combination of product quality and the level of cost resources for its production.

The main reserves or sources of reduction of operating costs are manifested in the process of more efficient use of instruments of labour, material and supplies and workforce. The main reserves of cost reduction can be divided into two categories: internal and external. The internal factors can include:

- improvement of the use of labour resources (improvement of production technology, optimal use of production opportunities, mechanization and automation of production processes);

- improvement of the production organization, labour and management (personnel development, optimization of management and labour, loss reduction of working time, improving the labour norm setting and motivation);

- improvement of the use of material and supplies (computerization of accounting, loss prevention from defective articles, standardization improvement of material costs, savings of material resources).

The external factors include:

- inflation processes in macroeconomics;

- prices for consumed resources;

- the tax burden on the enterprise;

- specialization and cooperation in the conditions of globalization and competition.
The cost systematic reduction ensures not only increase of the enterprise profitability but also gives additional means for further development.

The next stage is control over the process of cost formation, which means the comparison of the planned and actual indicators. In case of deviations, a regulation is made, because of which plans are changed, or there is an effect on the situation in order to bring it closer to the planned indicators. In this case, the regulation effectiveness indicator is the magnitude of the cost deviation for each resource. The closer the size of actual costs to the target, the closer the actual cost to the planned, taking into account the actual performance of the production program.

The control effectiveness is conditioned by corrective management actions aimed at bringing actual costs in line with planned or refined plans if these cannot be met because of objective changes in the production conditions. The timely coordination and cost management allow the company to avoid a major breakdown in accomplishing the planned economic performance.

\section{Conclusions}

Costs are an important aspect of each manufacturing enterprise. Costs form the products price and have a directinfluence on the financial results of the enterprise's work. With the same income level, the enterprise may have a profit or loss, depending on the costs' amount. Therefore, effective cost management is relevant to each manufacturing enterprise. The relevance of the research topic causes a significant amount of scientific work on cost management. Costs are considered by scientists from the position of different approaches: resource, economic, accounting, management, and marketing. There are different cost management methods that can be classified as traditional and market-based. For rational cost management at the enterprise, a cost management system must be established.

The cost management system should be aimed not only at the survival of the enterprise but also at the implementation of its tactical and strategic goals. The cost management, which will be aimed at achieving the above goals, is a rather complex process, because costs are variable and consist of numerous elements of different content and origin, depend on various factors, are sensitive to the external environment, often have a controversial composition and are difficult to adjust to desired regulation.

Summing up, we should note that the cost management system has a dual nature and can be considered as an independent system that includes subsystems and a set of interrelated elements that interact with each other to achieve a high economic performance of the enterprise. The improvement of the enterprise management system in modern economic conditions will not be effective without establishing an efficient cost management system, the creation of which is advisable to implement using both national and international practice. 


\section{References:}

Balan, A. A. (2014). Systema upravlinnya vytratamy na promyslovomu pidpryyemstvi [Cost management system in industrial enterprises]. Ekonomika: realiyi chasu, 3(13), 43-49.

Harkavenko, S. S. (2007). Marketynh [Marketing]. Kyiv: Libra. (in Ukrainian)

Deriy, V. A. (2015). Ekonomichni pokaznyky vytrat pidpryyemstva ta sobivartosti produktsiyi v obliku, statystytsi $y$ analizi [Economic Indicators of the Expenditures of Enterprise and the Costs of Production in Accounting, Statistics and Analysis]. Oblik i finansy, 2, 15-21.

Kaplan, R. S. (1998). Cost and Effect: Using Integrated Cost System to Drive Profitability and Performance. President and Fellows of Harvard College, USA.

Kozak, V. H. (2009). Vyznachennya ponyattya «vytraty» ta yikh otsinka [Definition of the "costs" concept and its estimation]. Reformuvannya ekonomiky Ukrayiny: stan ta perspektyvy : zb. mater. IV Mizhnar. nauk.-prakt. konf. (Ukrainian, Kyiv, November 26-27).

Kozachenko, H. V., Pohorelov, Yu. S., Makukhin, H. A. (2007). Upravlinnya zatratamy pidpryyemstva [Costs management of the enterprise]. Kyiv: Libra. (in Ukrainian)

Porter, M. E. (1990). The Competitive Advantage of Nations. New York: Free Press.

Skrypnyk, M. I. (2011). Orhanizatsiya obliku vytrat u rozrizi tsentriv vytrat ta tsentriv vidpovidalnosti [Organization of cost accounting in terms of cost centers and responsibility centers]. Oblik $i$ finansy APK. Kyiv: TOV YuF «Yur-Ahro-Vest», 1, 46-49.

Taler, T. V. (2006). Poshuk shlyakhiv znyzhennya sobivartosti produktsiyi promyslovoho pidpryyemstva [Searching the ways to reduce the productions cost of industrial enterprise]. Derzhava ta rehiony, 5, 415-417.

Cherep, A. V. (2005). Mozhlyvosti zastosuvannya novykh orhanizatsiynykh struktur upravlinnya z metoyu znyzhennya sobivartosti produktsiyi [Possibilities of application the new organizational structures of management in order to reduce the production's cost]. Visnyk Natsionalnoyi akademiyi derzhavnoho upravlinnya pry Prezydentovi Ukrayiny, 2, 208-215.

Chumachenko, M. H. (2008). Dyskusiyni problemy obliku vytrat i kalkulyuvannya sobivartosti produktsiyi [Discussion problems of costs accounting and the products cost calculation]. Bukhhalterskyy oblik $i$ audit, 10, 3-7.

Yudina, M. I. (2013). Analiz kryteriyiv ta napryamiv zmenshennya vytrat vyrobnytstva u sobivartosti produktsiyi [Analysis of criteria and ways of production expenditure reduction in product cost]. Visnyk Khmelnytskoho natsionalnoho universytetu. Ekonomichni nauky, 4(2), 98-102. 